\title{
Semantic ambiguity does not imply syntactic ambiguity
}

\section{A ambiguidade semântica não implica ambiguidade sintática}

\author{
Miguel López-Astorga \\ http://orcid.org/0000-0002-6004-0587-E-mail: milopez@utalca.cl
}

\begin{abstract}
A problem to solve in generative grammar is to account for why children are able to note when a sentence or expression is ambiguous, even if they have not received explicit training for that. The theory of mental models can give an explanation in that way. That explanation is based upon the idea that people interpret linguistic messages by considering the semantics models corresponding to them, and it has been also proposed that the syntactic structures of those messages can be recovered by taken those very models into account. However, the point of this paper is that it tries to show that ambiguity at semantic level, that is, the cases in which models referring to different facts can be attributed to one sentence, does not necessarily lead to ambiguity at syntactic level. As it is argued, it is possible to capture models describing several opposite circumstances by means of only one logical form.
\end{abstract}

Keywords: Ambiguity. Logical form. Model. Semantics. Syntax.

\section{RESUMO}

Um problema para resolver na gramática generativa é explicar por que os meninos são capazes de notar quando uma frase ou expressão é ambígua, mesmo que não tenham recebido ensino explícito para isso. A teoria dos modelos mentais pode dar uma explicação nesse sentido. Essa explicação é baseada na ideia de que as pessoas interpretam as mensagens linguísticas considerando os modelos

\footnotetext{
1 This paper is a result of Project CONICYT/FONDECYT/REGULAR/FOLIO № 1180013, "Recuperación de las formas lógicas de los enunciados a partir de un análisis de las posibilidades semánticas a las que hacen referencia ," supported by the National Fund for Scientific and Technological Development (FONDECYT, following its initials in Spanish), Government of Chile. The author also thanks Project "PIA Ciencias Cognitivas, Centro de Investigación en Ciencias Cognitivas, Instituto de Estudios Humanísticos, Universidad de Talca."
} 
semânticos correspondentes a elas, e foi proposto que as estruturas sintáticas dessas mensagens podem ser recuperadas tomando esses mesmos modelos em consideração. No entanto, o ponto deste trabalho é que tenta mostrar que a ambiguidade ao nível semântico, isso é, os casos nos que modelos se referindo a fatos diferentes podem ser atribuídos a uma frase, não necessariamente leva a uma ambiguidade ao nível sintático. Como é argumentado, é possível captar modelos descrevendo várias circunstâncias opostas por meio de uma só forma lógica.

Palavras-chave: Ambiguidade. Forma lógica. Modelo. Semântica. Sintaxe

\section{Introduction}

It has been raised that generative grammar has several problems to remove (HORNSTEIN 1987) and proposed that the theory of mental models (e.g., QUELHAS, RASGA, \& JOHNSONLAIRD, 2019) can do that (LOPEZ-ASTORGA, 2019a). However, this paper will be focused on only one of those problems: ambiguity. That problem refers to the fact that, although children are not explicitly taught to do that, they can often note whether an expression or sentence has a meaning that is not unique.

The explanations of the theory of mental models for those problems in general and the problem of ambiguity in particular are based upon a very important thesis of that theory: people process language by analyzing the semantic models or possibilities that can correspond to utterances (see also, e.g., KHEMLANI \& JOHNSON-LAIRD, 2019). Nevertheless, another interesting point in this way is that it has been claimed as well that, from those models, it is possible to identify the real formal or logical structures of sentences or expressions (e.g. LÓPEZ-ASTORGA, 2019b). Actually, the proponents of the theory of mental models reject both the idea of detecting syntactic structures from semantic models and ways to do that akin to that commented on below (e.g. JOHNSON-LAIRD, 2010). Nonetheless, the main aim of this paper is to show that the ambiguity at semantic models level does not necessarily lead to alternative logical forms. Or, in other words, that the fact that the meaning of a sentence is ambiguous does not necessarily cause doubts regarding its deep syntactic structure. Thus, in general, what will be argued is that each sentence has a logical form, and that, if a particular sentence seems to have more than one formal structure, such structures should be, somehow, equivalent. So, if a sentence is ambiguous, it has to be possible to express that ambiguity by means of its logical form, without the need to assume the possibility of that sentence having two or more different syntactic structures.

And to achieve that goal, the first section will describe the manner the theory of mental models can account for ambiguity in the cases in which a sentence that does not appear to be univocal in natural language is processed. Then, the way logical forms can be obtained from semantic models will be explained. Lastly, the reasons why the ambiguity in sentences in natural language does not have an influence on their real logical forms, as well as the mode just one logical form can capture the same degree of ambiguity as its sentence in natural language, will be indicated.

\section{The theory of mental models and ambiguity in natural language}

As said, the theory of mental models can solve various problems in generative grammar. Those problems are related to the language learning process (HORNSTEIN, 1987). However, as also indicated, the focus here will be just on the difficulties linked to the fact that children can, without receiving specific instruction, identify when expressions are not clear. 
The account that can be given for that problem from the theory of mental models is relatively simple (see LÓPEZ-ASTORGA, 2019a, where is basically presented the explanation that will be described in this section). The theory proposes to assign iconic possibilities - called 'models' - to expressions in natural language (see also, e.g., HINTERECKER, KNAUFF, \& JOHNSONLAIRD, 2016; JOHNSON-LAIRD, 2012, 2015; JOHNSON-LAIRD, KHEMLANI, \& GOODWIN, 2015; KHEMLANI \& JOHNSON-LAIRD, 2019; LÓPEZ-ASTORGA, 2019b; QUELHAS, RASGA, \& JOHNSONLAIRD, 2017). Obviously, such models iconically stand for different situations in which an utterance can be true. This can be clear by means of an example:

(1) "Peter and John began to run and he fell to the ground" (LÓPEZ-ASTORGA, 2019a, p. 239).

A sentence such as this one can be deemed as ambiguous because it can be true in at least two different possibilities:

(1.a) "Peter and John began to run \& Peter fell to the ground" (LÓPEZ-ASTORGA, 2019a, p. 239).

(1.b) "Peter and John began to run \& John fell to the ground" (LÓPEZ-ASTORGA, 2019a, p. 239).

(1.a) and (1.b) are the models corresponding to (1). However, the point is that, according to this account, children are able to note that (1) does not have just one meaning because, although no teaching is given in this way, they have the ability to detect that its models are, at a minimum, (1.a) and (1.b).

Nonetheless, as mentioned, a method to discover logical forms for sentences from iconic possibilities of the theory of mental models such as (1.a) and (1.b) has been developed. In principle, one might think that, because (1) has two models - (1.a) and (1.b) - any method to recover its actual syntactic structure based upon its iconic possibilities should lead to at least two different logical forms that cannot be reduced to each other. But this is not necessarily the case. Its ambiguity can also be expressed by means of only one simple logical form. This is explained below. However, it is first shown the exact manner logical forms can be derived from possibilities such as those of the theory of mental models.

\section{Relations between syntactic structures and semantic models}

There are several works where the method to draw logical forms from semantic models akin to the ones proposed by the theory of mental models is presented. Nevertheless, this section will pay attention just to one particular example (which is analyzed, among other works, in LÓPEZ-ASTORGA, 2019b, the paper that will be essentially followed in this section). The example begins with this sentence:

(2) “...Eva read Don Quixote or a novel" (KHEMLANI, BYRNE, \& JOHNSON-LAIRD, 2018, p. 1899; italics in text; see also, e.g., LÓPEZ-ASTORGA, 2019b, p. 76).

Example (2) really refers to a sentence used in several papers about the theory of mental models (e.g., in LÓPEZ-ASTORGA, 2019b, it is cited the study by ORENES \& JOHNSON-LAIRD, 2012). However, the most important point now is that two possibilities can be thought for it:

(2.a) Eva $_{[i]}$ read Don Quixote \& she ${ }_{[i]}$ read a novel

(2.b) Eva $_{[i]}$ did not read Don Quixote and she ${ }_{[i]}$ read a novel

Possibilities (2.a) and (2.b) are akin to, for instance, models [I] and [II] in López-Astorga (2019b), and, of course, are also coherent with the models indicated for (2) in papers such as 
Khemlani et al. (2018). On the other hand, the use of the subindex' ' ' in them fulfills the same function as in, for example, Hornstein (1995), that is, to point out that the words have exactly the same reference.

Nevertheless, perhaps what is relevant here is that, given that 'or' appears in (2), one might think that its logical form is the one of the logical disjunction. But, if its models are analyzed in order to find its real logical structure, that task can show that such idea is not correct.

Actually, what is made in works trying to derive logical forms from models (such as, e.g., that of LÓPEZ-ASTORGA, 2019b) is something that, as indicated, in a more or less explicit way, the theory of mental models does not accept (e.g., JOHNSON-LAIRD, 2010). This last theory considers logical form to be unnecessary to explain cognition (which is also reminded in papers such as the one of LÓPEZ-ASTORGA, 2019b). Nonetheless, the proposal trying to recover logical forms from iconic possibilities claims that models such as (2.a) and (2.b) can be deemed as cases in a fictitious truth table, which can reveal a formula that is true in precisely those two cases.

Thus (always following, as mentioned, basically the paper by LÓPEZ-ASTORGA, 2019b), if it is understood that (2.a) represents a case in which the two propositions are true (i.e., a case in which it is true both that Eva read Don Quixote and that she read a novel), that (2.b) represents a case in which only the second proposition is true (i.e., a case in which it is only true that Eva read a novel), and that the logical form that is looked for can be true only in those two exact situations, it is evident that possible options can be these ones:

(3) $(p \vee \neg p) \rightarrow q$

(4) $q$

Where ' $p$ ' stands for the fact that Eva read Don Quixote, ' $q$ ' refers to the fact that Eva read a novel, ' $\vee$ ' is the logical disjunction, ' $\neg$ ' means negation, and ' $\rightarrow$ ' represents the material conditional.

Formulae (3) and (4) are literally formulae [VI] and [VII] in López-Astorga (2019b). However, what is interesting for this paper is that, although both of them can be attributed at once to (2), that does not mean that this method is not precise, and that, actually, it is possible to think about more than one deep syntactic structure for each sentence. As it is well known, (3) and (4) are logically equivalent, and they are that because, as argued, they are true in exactly the same cases in the fictional truth table created for (2). Therefore, that (3) and (4) are two formulae, and not just one, is not a real problem, since they are linked to the same formal structure. And, of course, the same could be said with regard to any other formula that could also be true in only those particular cases.

The next section is focused on (1) from this very perspective. It is intended to show that, in spite of its ambiguity, only equivalent formulae can be assigned to it as well.

\section{Ambiguity in natural language and logical form}

Because of the ambiguity of (1), one might think that, in principle, at least two logical forms can be attributed to it:

(5) $r \wedge s \wedge t$

(6) $r \wedge s \wedge u$

Where ' $\wedge$ ' represents the logical conjunction, ' $r$ ' stands for the fact that Peter began tor run, 's' refers to the fact that John began to run, ' $t$ ' indicates the fact that Peter fell to the ground, and ' $u$ ' is the symbol corresponding to the fact that John fell to the ground. 
However, as pointed out in the specialized literature (e.g., although to reject these procedures and support a primacy of aspects such as semantics over syntax, JOHNSON-LAIRD, 2010), (5) and (6) can be easily transformed into one only syntactic structure:

$$
\text { (7) }(r \wedge s \wedge t) \vee(r \wedge s \wedge u)
$$

Clearly, (7) is already an only logical form that can be assigned to (1) and that is able to capture its ambiguity. So, as stated above, ambiguity in natural language and at semantic models level does not necessarily lead to ambiguity at logical forms level. Nevertheless, this idea can be even further strengthened. Following arguments presented in the literature (e.g., JOHNSON-LAIRD, 2010; however, again, the arguments are used in this last paper to be rejected and to argue that syntax is not necessary in cognition), it could be thought that, from (7), much simpler formulae such as (8) could be in turn inferred:

$$
\text { (8) }(r \wedge s) \wedge(t \vee u)
$$

Which can capture the ambiguity in (1) as well.

Actually, it is true that this kind of methods have been questioned (as said, e.g., in JOHNSON-LAIRD, 2010). But this usually happens in works about mainly reasoning or thinking. Thus, the chief idea is generally that, to explain human reasoning and thinking, it is enough to take models such as (1.a), (1.b), (2.a), and (2b) into account, logical form being superfluous. Nevertheless, such criticisms can be ignored here for, at a minimum, one clear reason. What is interesting for this paper is not just cognition, but also linguistics (this is also so in papers such as, e.g., LÓPEZ-ASTORGA, 2019a, 2019b, which allows ignoring those criticisms in them too). Accordingly, the main point to which should be paid attention in this section is simply that, as in the case of (2), (3), and (4), the fact that both (7) and (8) can be assigned to (1) does not imply ambiguity regarding the formal structure of this last sentence. In this way, it is not hard to note that the truth tables of (7) and (8) are equivalent too.

Furthermore, from (7) and (8), even well-formed formulae in first-order predicate calculus consistent with them can be built. Indeed, if this last type of logic is preferred, it is also possible to think about formulae such as these:

$$
\begin{aligned}
& \text { (9) }(\mathrm{Ra} \wedge \mathrm{Rb} \wedge \mathrm{Fa}) \vee(\mathrm{Ra} \wedge \mathrm{Rb} \wedge \mathrm{Fb}) \\
& (10)(\mathrm{Ra} \wedge \mathrm{Rb}) \wedge(\mathrm{Fa} \vee \mathrm{Fb})
\end{aligned}
$$

Where ' $R$ ' represents the action of beginning to run, ' $F$ ' refers to the action of falling to the ground, ' $a$ ' is Peter, and ' $b$ ' is John.

Obviously, (9) is directly related to (7), and (10) to (8). But what is important is that, given that (9) can be constructed from (7), and (10) from (8), and that (7) and (8) are, as indicated, equivalent, it can be said that all of these formulae are coherent with each other. Hence, the fact that all of them can be linked to (1) causes neither difficulties nor ambiguity.

\section{Conclusions}

There is no doubt that, as it has been shown (e.g., LÓPEZ-ASTORGA, 2019a), the theory of mental models is a framework with the necessary resources to account for many linguistic 
problems, including the one addressed in this paper. Effectively, the theory has no any problems to deal with the situations in which children can identify sentences in natural language that are ambiguous, and that without acquiring explicit learning to do it.

On the other hand, it is also obvious that the iconic possibilities of the theory of mental models can be used to recover syntactic structures. This point has been made in several works as well (one of them, e.g., LÓPEZ-ASTORGA, 2019b).

Thus, it can be claimed that this paper clearly confirms those two points. From an account based on the theory of mental models that can be found in the literature (in particular, in LÓPEZASTORGA, 2019a) trying to solve the problem related to (1), that is, the problem of how a child without explicit instruction for that can note its ambiguity, it shows how the models corresponding to a sentence allow coming to the deep formal structure of that very sentence.

But there is also a novelty here. The paper reveals that, while the ambiguous expressions in natural language should be linked to several iconic possibilities to capture that ambiguity, the syntactic structures to which it is possible to come from them can be completely exact and unequivocal. As also argued, that does not mean that the logical form cannot consider the ambiguity characterizing the expression in natural language. Despite their accuracy and uniqueness, logical forms can, at the same time, do that. In fact, that is clearly what can be said about (7), (8), (9), and (10).

Strictly speaking, these last formulae are different, which can lead skeptics to object that, at least somehow, ambiguity keeps existing at syntactic level. The argument could be that, although logical forms are not ambiguous, ultimately, there are various logical forms that can be related to (1), and not just one. However, it is also evident that, as stated, those four formulae are absolutely compatible. Either of them can be replaced, if that is interesting, necessary, or opportune, by either of the others. Hence, it can be claimed that they can be true in precisely the same circumstances. This in turn can lead one to think that they are fundamentally more complex or simpler versions, depending on the perspective assumed, of the same syntactic structure.

\section{References}

HINTERECKER, T., KNAUFF, M., \& JOHNSON-LAIRD, P. N. Modality, probability, and mental models. Journal of Experimental Psychology: Learning, Memory, and Cognition, v. 42, n. 10, 2016. p. 1606-1620.

HORNSTEIN, N. Logic as Grammar: An Approach to Meaning in Natural Language. Cambridge, MA:The Massachusetts Institute of Technology (MIT) Press, 1987.

HORNSTEIN, N. Logical Form: From GB to Minimalism. Cambridge, MA, \& Oxford, UK: Blackwel, 1995.

JOHNSON-LAIRD, P. N. Against logical form. Psychologica Belgica, v. 50, n. 3/4, 2010. p. 193-221.

JOHNSON-LAIRD, P. N. Inference with mental models. In: Holyoak, K. J. \& R. G. Morrison, R. G. (Eds.). The Oxford Handbook of Thinking and Reasoning. New York, NY: Oxford University Press, 2012.

JOHNSON-LAIRD, P. N. How to improve thinking. In: WEGERIF, R., Li, L., \& KAUFMAN, J. C. (Eds.). The Routledge International Handbook of Research on Teaching Thinking. Abingdon, UK, \& New York, NY: Routledge, 2015.

JOHNSON-LAIRD, P. N., KHEMLANI, S., \& GOODWIN, G. P. Logic, probability, and human reasoning. Trends in Cognitive Sciences, v. 19, n. 4, 2015. p. 201-214. 
KHEMLANI, S., BYRNE, R. M. J., \& JOHNSON-LAIRD, P. N. Facts and possibilities: A model-based theory of sentential reasoning. Cognitive Science, v. 42, n. 6, 2018. p. 1887-1924.

KHEMLANI, S. \& JOHNSON-LAIRD, P. N. Why machines don't (yet) reason like people. Künstliche Intelligenz, 2019. Retrieved from: https://link.springer.com/article/ 10.1007\%2Fs13218-01900599-w\#aboutcontent.

LÓPEZ-ASTORGA, M. Language acquisition and innate cognitive abilities: An approach from the mental models theory. Círculo de Lingüística Aplicada a la Comunicación (CLAC), n. 77, 2019a. p. 233-242.

LÓPEZ-ASTORGA, M. Possible roles for semantics and syntax in a government-binding structure. Prometeica, n. 19, 2019b. p. 72-79.

ORENES, I. \& JOHNSON-LAIRD, P. N. Logic, models, and paradoxical inferences. Mind \& Language, v. 27, n. 4, 2012. p. 357-377.

QUELHAS, A. C., RASGA, C., \& JOHNSON-LAIRD, P. N. A priori true and false conditionals. Cognitive Science, v. 41, n. 55, 2017. p. 1003-1030.

QUELHAS, A. C., RASGA, C., \& JOHNSON-LAIRD, P. N. The analytic truth and falsity of disjunctions. Cognitive Science, v. 43, n. 9, 2019. Retrieved from: https://modeltheory.org/papers/2019analytictruth-disjns.pdf

\section{Sobre o autor}

\section{Miguel Lopéz-Astorga}

Ph.D. in Logic and Philosophy of Science (University of Cádiz, Spain).

Institutional affiliation: Full Professor at the Institute of Humanistic Studies "Juan Ignacio Molina," University of Talca, Talca Campus, Chile. 